\title{
Inhibition of lignin-derived phenolic compounds to cellulase
}

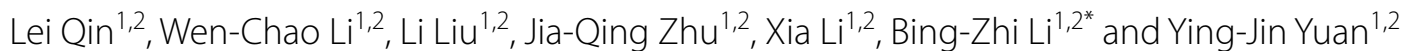

\begin{abstract}
Background: Lignin-derived phenolic compounds are universal in the hydrolysate of pretreated lignocellulosic biomass. The phenolics reduce the efficiency of enzymatic hydrolysis and increase the cost of ethanol production. We investigated inhibition of phenolics on cellulase during enzymatic hydrolysis using vanillin as one of the typical ligninderived phenolics and Avicel as cellulose substrate.

Results: As vanillin concentration increased from 0 to $10 \mathrm{mg} / \mathrm{mL}$, cellulose conversion after 72 -h enzymatic hydrolysis decreased from 53 to $26 \%$. Enzyme deactivation and precipitation were detected with the vanillin addition. The enzyme concentration and activity consecutively decreased during hydrolysis, but the inhibition degree, expressed as the ratio of the cellulose conversion without vanillin to the conversion with vanillin $\left(A_{d} / A\right)$, was almost independent on hydrolysis time. Inhibition can be mitigated by increasing cellulose loading or cellulase concentration. The inhibition degree showed linear relationship with the vanillin concentration and exponential relationship with the cellulose loading and the cellulase concentration. The addition of calcium chloride, BSA, and Tween 80 did not release the inhibition of vanillin significantly. $\mathrm{pH}$ and temperature for hydrolysis also showed no significant impact on inhibition degree. The presence of hydroxyl group, carbonyl group, and methoxy group in phenolics affected the inhibition degree.
\end{abstract}

Conclusion: Besides phenolics concentration, other factors such as cellulose loading, enzyme concentration, and phenolic structure also affect the inhibition of cellulose conversion. Lignin-blocking agents have little effect on the inhibition effect of soluble phenolics, indicating that the inhibition mechanism of phenolics to enzyme is likely different from insoluble lignin. The inhibition of soluble phenolics can hardly be entirely removed by increasing enzyme concentration or adding blocking proteins due to the dispersity and multiple binding sites of phenolics than insoluble lignin.

Keywords: Phenolics, Vanillin, Inhibition, Cellulose, Enzymatic hydrolysis, Cellulase

\section{Background}

Biorefinery of lignocellulosic biomass to liquid fuels or other chemicals is beneficial to sustainable energy and environment [1]. Lignocellulose is mainly composed of cellulose, hemicellulose, and lignin. Cellulose and hemicellulose can be converted to fermentable sugars by enzymatic hydrolysis, while lignin plays a negative role on the saccharification of lignocellulosic biomass [2]. Lignin is

\footnotetext{
*Correspondence: bzli@tju.edu.cn

${ }^{2}$ SynBio Research Platform, Collaborative Innovation Center of Chemical Science and Engineering (Tianjin), Tianjin University, Weijin Road 92,

Nankai District, Tianjin 300072, People's Republic of China

Full list of author information is available at the end of the article
}

an aromatic polymer consisting of three primary units: hydroxyphenyl $(\mathrm{H})$, guaiacyl $(\mathrm{G})$, and syringyl (S) units, which are randomly linked with aryl ether, ester, or carbon bonds. Lignin adheres the carbohydrates together and strengthens the cell wall structure to give rise to biomass recalcitrance [3-5].

Pretreatment is requisite to break the biomass recalcitrance by changing chemical or physical properties of biomass and thus increase the enzyme accessibility to cellulose [6,7]. Delignification not only enhances cellulose digestibility by increasing the accessibility of cellulose but also reduces the adsorption of cellulase on lignin [8-10]. Lignin inhibition caused by non-productive enzyme 
adsorption has been deeply studied in the past few years [11-14]. During the pretreatment, lignin is generally degraded into kinds of phenolics or oligomers. Both complete lignin [8-14] and soluble lignin derivatives (phenolics) [15-17] after pretreatment process hamper enzyme hydrolysis and reduce sugar yields. Understanding and reducing the inhibition of phenolics in enzymatic hydrolysis are an important issue to improve the efficiency of bioconversion of lignocellulose.

Soluble phenolics are generally generated during most pretreatment processes, such as acidic or alkaline pretreatment, regardless of herbage, softwood or hardwood [18, 19]. The type and content of soluble phenolics are up to the biomass species and the pretreatment methods, and phenolics concentration also depends on the solid loading in pretreatment and enzymatic hydrolysis. Dry-to-dry pretreatment process (e.g., AFEX and ethylenediamine pretreatment) $[20,21]$ saves water usage as well as increases soluble phenolics concentration in the subsequent enzymatic hydrolysis. Increasing solid loading in enzymatic hydrolysis also increases the phenolics concentration significantly [22]. Previous studies supposed that the degraded lignin is less harmful to enzymes than macromolecular lignin [23, 24]. However, phenolics are much more inhibitory than soluble sugars, furan derivatives, and organic acids, as phenolics can lead to precipitation and irreversible inhibition of enzymes [13, 17]. Furthermore, cellulase is found more susceptible to be inhibited than $\beta$-glucosidase $[13,15]$. Inhibition degree of phenolics depends on phenolics concentration with linear correlation or non-linear correlations $[25,26]$. However, our knowledge about inhibition of phenolics is still limited to overcome the problem.

In this study, a commercial enzyme Spezyme CP containing exo-, endo-cellulase, and $\beta$-glucosidase activities was used to examine the effect of phenolics on cellulase mixture. We used pure cellulose (Avicel) as substrate to avoid the interference of other compositions in lignocellulosic materials. Vanillin was employed as model phenolic, due to its common existence in pretreated lignocellulose [18, 22]. We investigated the effects of cellulose concentration, cellulase concentration, $\mathrm{pH}$, and temperature on the inhibition of phenolics to enzymatic activity. Furthermore, we tried to reduce phenolics inhibition by adding non-active proteins and surfactants. The fundamental insights would be constructive to understand the mechanism of phenolics inhibition and improve the enzymatic hydrolysis of lignocellulosic biomass.

\section{Results and discussion}

Phenolics denature and inhibit cellulose during enzymatic hydrolysis of cellulose

As vanillin is a main phenolic compound from lignin degradation, we studied the effect of different vanillin concentrations on cellulose conversion catalyzed by a commercial cellulase (Spezyme CP) in hydrolysate (Fig. 1). Our study indicated that the phenolics concentration in the hydrolysate of ethylenediamine pretreated corn stover with high solid loading reaches $10 \mathrm{mg} /$ $\mathrm{mL}$. The addition of $1-10 \mathrm{mg} / \mathrm{mL}$ vanillin resulted in decreased cellulose conversions (Fig. 1a) and decreased hydrolysis rate (Additional file 1: Figure S1). We further calculated apparent inhibition degree ( Inhibition $_{\text {app }}$ ) based on the control (cellulose conversion without inhibitor addition) as following equation:

$$
\text { Inhibition }_{\text {app }}=1-A / A_{0}
$$

where $A$ is cellulose conversion with inhibitor at specific hydrolysis time; $A_{0}$ is cellulose conversion without inhibitor at the same hydrolysis time and the same condition with $A$.

It is obvious that inhibition ${ }_{\text {app }}$ is nearly a constant at $10 \mathrm{mg} / \mathrm{mL}$ vanillin (within a range from 50 to $54 \%$ ), and inhibition $_{\text {app }}$ slightly decreased at lower vanillin concentrations $(1-5 \mathrm{mg} / \mathrm{mL})$ along with the hydrolysis time (e.g., inhibition $_{\text {app }}$ of $5 \mathrm{mg} / \mathrm{mL}$ vanillin decreased from 39 to $32 \%$ within 72 h) (Fig. 1b). The decrease of inhibition ${ }_{\text {app }}$ at lower inhibitor concentration may be ascribed to the product inhibition by glucose and cellubiose, because the glucose and cellubiose accumulated to a high concentration at the later hydrolysis stages [22].

Enzyme concentrations in supernatant at different conditions were determined (Additional file 2: Figure S2). Without cellulose substrate addition, cellulase concentration decreased by $42 \%$ after 72 -h incubation in citrate buffer under the same condition of enzymatic hydrolysis $\left(50{ }^{\circ} \mathrm{C}, \mathrm{pH} 4.8\right)$, which is due to the thermal denaturation of enzymes. The enzyme activity at different incubation times also decreased, consistent with enzyme concentration (Additional file 3: Figure S3). In the real enzymatic hydrolysis, enzyme concentration was lower than that without substrate in initial $3 \mathrm{~h}$ due to the productive adsorption in substrate. However, the enzyme concentration with substrate became higher than that without substrate after 24 h (Additional file 2: Figure S2). This result revealed that the binding of enzymes and substrate benefits to maintain the enzyme activity. In addition, with the addition of vanillin, cellulase concentration after $72 \mathrm{~h}$ decreased by 58 and $54 \%$ for that with and without substrate addition, respectively, which indicated that vanillin accelerated the denaturation of cellulase (Additional file 2: Figure S2). The enzyme activity with vanillin addition decreased from 45 to $13 \%$ from 24 to $72 \mathrm{~h}$ (Additional file 3: Figure S3), while the enzyme concentration only decreased from 0.17 to $0.14 \mathrm{mg} / \mathrm{mL}$ at the same time (Additional file 2: Figure S2). This inconsistence of 


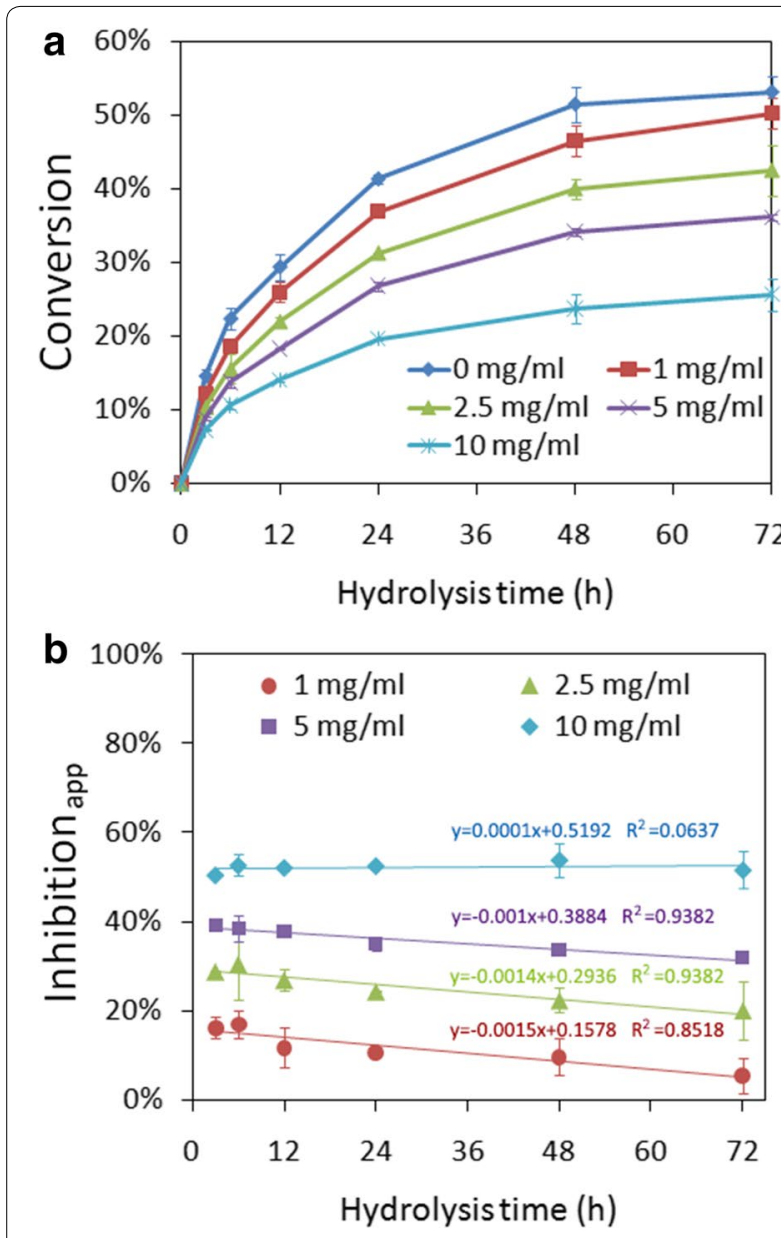

Fig. 1 Effect of vanillin concentration on enzymatic hydrolysis (a) and apparent inhibition degrees (b) during cellulose conversion. Cellulose loading was $1 \%(10 \mathrm{mg} / \mathrm{mL})$ and cellulase concentration was $0.3 \mathrm{mg} / \mathrm{mL}$. Error bars represented standard deviations, $n=3$

enzyme activity and enzyme concentration implied the accessional inhibition of vanillin on cellulase activity apart from protein denaturation. Inhibition of phenolics on cellulase in hydrolysate was a complicated course, including irreversible inhibition and reversible inhibition simultaneously [13].

\section{Effect of cellulase concentration and cellulose loading on inhibition}

As previously speculated, increasing cellulase loading may relieve the inhibition of phenolics [27]. We investigated the inhibition of vanillin on cellulose hydrolysis with different enzyme concentrations (Fig. 2). Cellulose conversion obviously increased as enzyme concentration increasing (Fig. 2a). However, as the function (1) defined, the apparent inhibitions decreased slightly along with the increasing enzyme concentration (Fig. 2b). For example, at $10 \mathrm{mg} / \mathrm{mL}$ vanillin, inhibition ${ }_{\text {app }}$ only decreased from
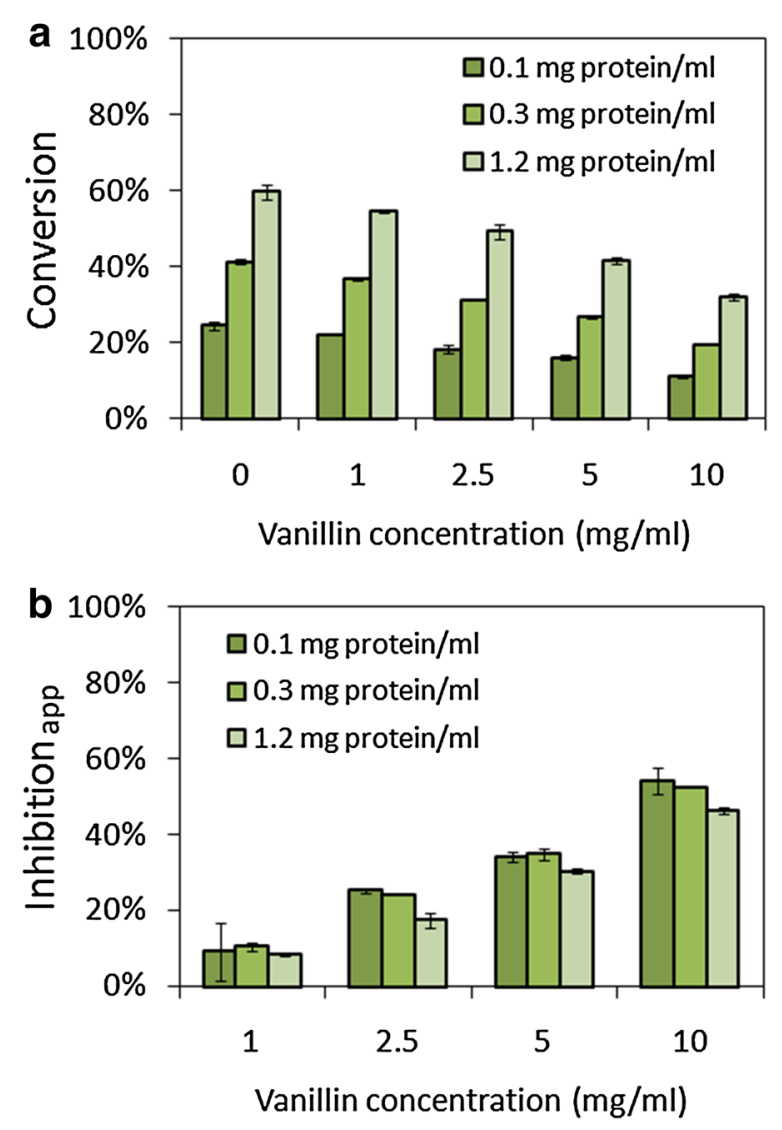

Fig. 2 Effect of enzyme concentration on cellulose conversions (a) and apparent inhibition (b) at $24 \mathrm{~h}$ of hydrolysis. Cellulose loading was $1 \%$. Error bars represented standard deviations, $n=3$

54 to $46 \%$ when enzyme concentration increased from 0.1 to $1.2 \mathrm{mg} / \mathrm{mL}$. These results indicated that increasing cellulase concentration slightly reduced inhibition ${ }_{\text {app }}$. The higher enzyme concentration than this range was not studied here. The effect of cellulose concentration on remission of vanillin inhibition was also investigated (Fig. 3). The subtle decrease of inhibition ${ }_{\text {app }}$ was also observed by increasing cellulose concentration except for $1 \mathrm{mg} / \mathrm{mL}$ vanillin (Fig. 3b). The reduction of inhibition ${ }_{\text {app }}$ was not significant at $1 \mathrm{mg} / \mathrm{mL}$ vanillin.

As enzyme concentration, cellulose concentration and inhibitor concentration proportionally increased, inhibition significantly increased (Additional file 4: Figure S4), which indicated that comparing to the increasing of enzyme concentration or cellulose concentration, the increasing of inhibitor concentration was more significant to affect the inhibition degree. This result proves that the declined cellulose conversion with higher solid loading in enzymatic hydrolysis is attributed to the increasing inhibitor concentration in many reports $[22,28]$. 


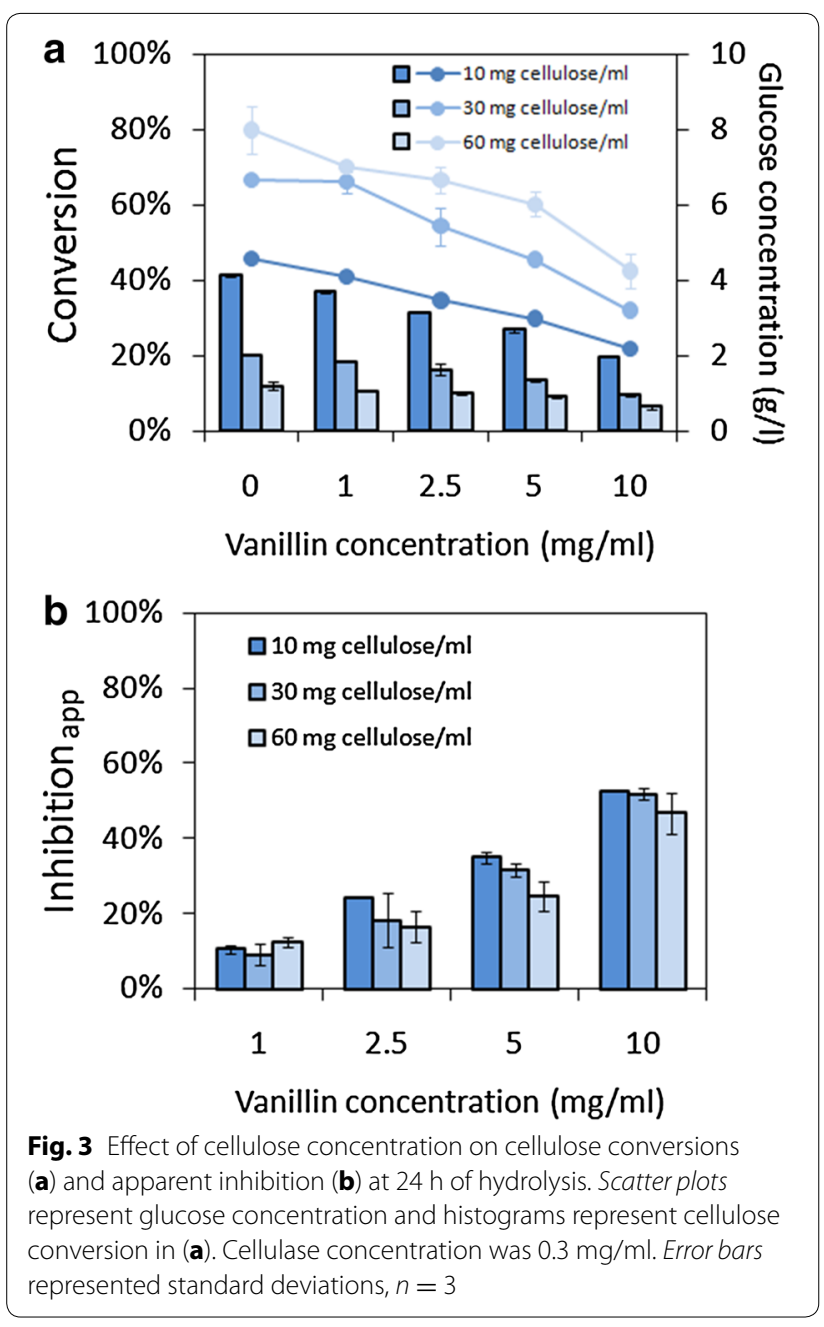

Although the remission of inhibition by increasing enzyme concentration and cellulose concentration is limited, the reason for this tiny remission was unknown. It was proposed that the equilibrium between adsorption of enzyme on cellulose and the denaturation of enzyme by inhibitor would regulate the effect of enzyme concentration and cellulose concentration on the inhibition. Inhibitor-binding constant [25] was employed to analyze the results. In the studies of reversible inhibition from glucose and cellubiose, the ratio of cellulose conversion without inhibitor to that with inhibitor $\left(A_{O} / A\right)$ has a linear relationship with inhibitor concentration as following expression:

$$
A_{0} / A=1+\beta I
$$

where $I$ is the concentration of inhibitor $(\mathrm{g} / \mathrm{L}) ; \beta$ is the inhibitor-binding constant $(\mathrm{L} / \mathrm{g})$. The higher $\beta$ value means the stronger combining capacity of inhibitor to enzyme.

Previous study determined $\beta$ values of several kinds of phenolics [29]. We found that the inhibition of vanillin was applicable to this equation as well, as shown in Fig. 4. The high relevance between $\left(A_{0} / A\right)$ and inhibitor concentration was observed. The value of $\beta$ decreased as enzyme concentration and cellulose concentration increasing, suggesting that the binding ability between enzyme and inhibitor reduced.

According to the experimental data between cellulose concentration, enzyme concentration, and $\beta$ values (Additional file 5: Table S1), we tried to develop an empirical model using nonlinear regression analysis. The exponential equation was the best fitting model, as shown in Fig. 5 and expressed by the following formula:

$$
\begin{aligned}
\beta= & 0.02788+0.1069 \times \exp (-0.009634 S) \\
& \times \exp (-0.4322 E)
\end{aligned}
$$

where $S$ is the cellulose concentration $(\mathrm{mg} / \mathrm{mL})$ and $E$ is the enzyme concentration $(\mathrm{mg} / \mathrm{mL})$.

As a result, the value of $A_{0} / A$ can be expressed as the function of cellulose, enzyme, and inhibitor concentration by substituting Eq. (3) into Eq. (2). The inhibition is positive correlation with inhibitor concentration and negative correlation with cellulose and enzyme concentrations. From Eqs. (2) and (3), we can see that the impact of inhibitor concentration on inhibition is much greater than cellulose and enzyme concentrations, because $A_{0} / A$ has linear relation with inhibitor concentration and is exponential rates-of-change with cellulose and enzyme concentration. As inhibitors are usually coupled with cellulose in the pretreated biomass, the inhibition increases as substrate loading increasing. It is notable that this relation is suitable when the enzyme is not excessive. Moreover, inhibition was determined with specific substrate, enzyme, and inhibitor at $50{ }^{\circ} \mathrm{C}$ and $\mathrm{pH}$ 4.8. The coefficients in Eq. (3) and the inhibition degree may vary with these conditions changing. Nonetheless, the linear relationship with inhibitor concentration and the exponential relationship with cellulose and enzyme concentration revealed the effects of cellulosic substrates, enzymes, and phenolics on inhibition.

\section{Effect of additives on inhibition}

In order to reduce the inhibition of phenolics, calcium chloride, BSA, Tween 80, and activated carbon were added into the hydrolysate with the presence of vanillin (Table 1). Calcium chloride was proven to be effective at reducing lignin inhibition through the formation of lignin-metal complex [30]. BSA can attach lignin and significantly reduce non-specific adsorption of cellulase on lignin, leaving more cellulase free in solution [10, 31]. Tween series were also shown to enhance enzymatic digestibility of pretreated biomass [32, 33]. However, these additives did not improve the cellulose conversion 

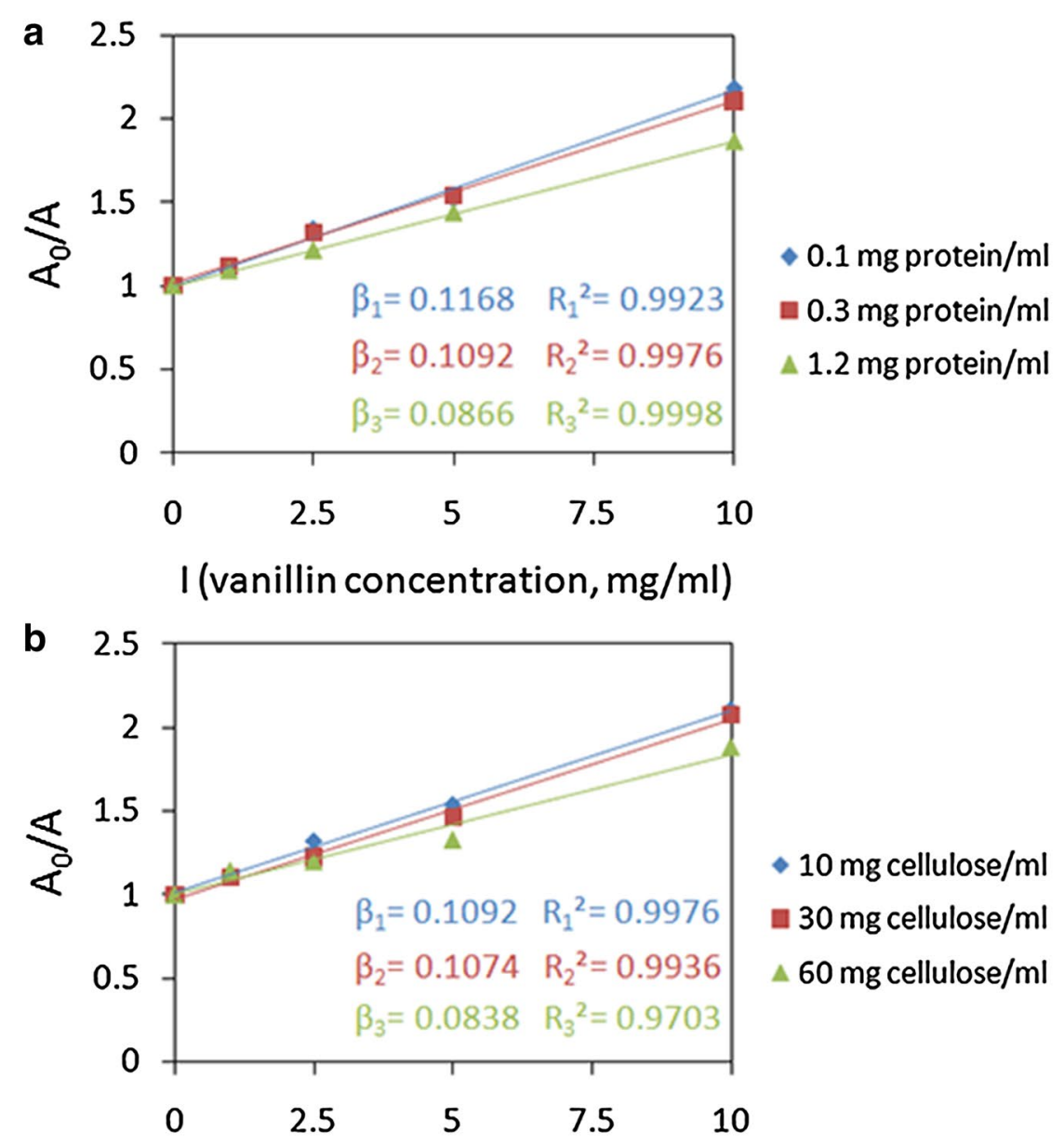

I (vanillin concentration, $\mathrm{mg} / \mathrm{ml}$ )

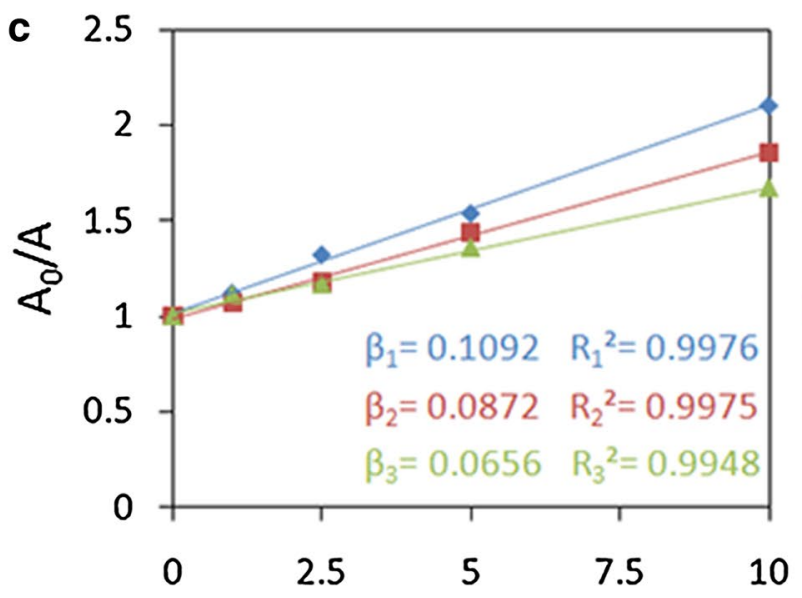

$10 \mathrm{mg}$ cellulose $/ \mathrm{ml}$ $0.3 \mathrm{mg}$ protein $/ \mathrm{ml}$

a $30 \mathrm{mg}$ cellulose $/ \mathrm{ml}$ $0.9 \mathrm{mg}$ protein $/ \mathrm{ml}$ $\triangle 60 \mathrm{mg}$ cellulose $/ \mathrm{ml}$ $1.8 \mathrm{mg}$ protein $/ \mathrm{ml}$

I (vanillin concentration, $\mathrm{mg} / \mathrm{ml}$ )

Fig. 4 Linear relationship between $A_{0} / A$ and vanillin concentration. a Different cellulase concentrations (cellulose loading was $1 \%$ ); b Different cellulose loadings (cellulase concentration was $0.3 \mathrm{mg} / \mathrm{ml}$ ); c Different cellulase concentrations and cellulose loadings 

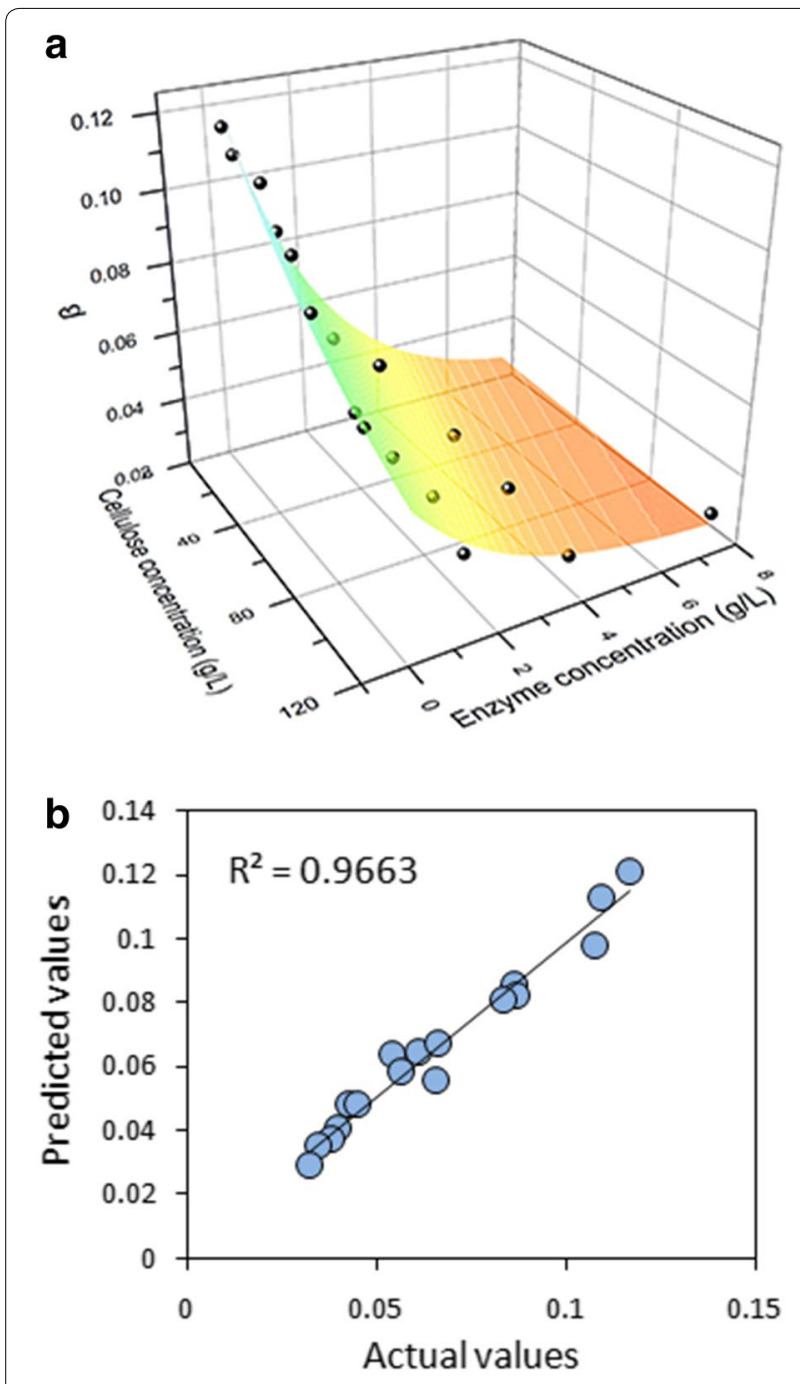

Fig. 5 Curve fitting of $\beta$ value. a Relationship between $\beta$, cellulose concentration and enzyme concentration; b Predicted $\beta$ values versus actual $\beta$ values using the exponential equation

in the absence and presence of vanillin. The BSA-preincubated trial exhibited no different cellulose conversions from the non-pre-incubated trial, which revealed that the effect of blocking agents on soluble inhibitors is negligible. The same to other additives, the results indicated that these kinds of additives would not be expected to have a major impact on the inhibition of soluble inhibitors. It also demonstrated that the inhibition mechanism of phenolics was different from insoluble lignin.

\section{Hypothesis of the interaction between phenolics, enzyme, and cellulose}

The decrease of the inhibitor-binding constant is probably due to the higher affinity between enzyme and cellulose than that between enzyme and inhibitor.
When enzyme concentration increased, more additional enzyme reacted with cellulose, and less additional enzyme was deactivated by phenolic inhibitor, causing the proportion of deactivated enzyme reduced comparing to original enzyme loading. Likewise, increasing cellulose concentration increased the proportion of active enzyme to cellulose and reduced the proportion of deactivated enzyme. Thus, inhibitor-binding ability was decreased comparing to former conditions (Fig. 6). Previous study showed that phenolics concentration in hydrolysate was also consumed with the precipitation of enzymes, supporting phenolics and enzymes are tightly bonded. A high ratio of $25 \mathrm{mg}$ protein/mg phenolics can exhaust phenolics gradually [17]. It was reported that the inhibition of macromolecular lignin in steam pretreated biomass can be overcome by increasing enzyme concentration [27]. The difference between inhibition of phenolics and inhibition of lignin is supposed to be as follows: the adsorption sites of macromolecular lignin are limited and can be saturated by increasing protein concentration, resulting in elimination of inhibition; in contrast, the inhibition of soluble phenolics can hardly be entirely removed by increasing enzyme concentration or adding blocking protein due to the dispersity and multiple binding sites of phenolics, which was proved by the BSA addition test. Hence, other detoxification methods are needed to overcome phenolic inhibitors.

\section{Effect of $\mathrm{pH}$ and temperature on inhibition}

Inhibition of vanillin was determined at different $\mathrm{pH}$ (4.35.3) and different temperatures $\left(30-50{ }^{\circ} \mathrm{C}\right)$ in enzymatic hydrolysis. Increasing $\mathrm{pH}$ slightly released inhibitionapp (Table 2). Glucan conversion with inhibitor addition kept at $\sim 27 \%$ at three $\mathrm{pH}$ values. Inhibition app reduced only from 35.7 to $32.6 \%$ when $\mathrm{pH}$ increased from 4.3 to 5.3, and the corresponding inhibitor-binding constant reduced from 0.111 to 0.097 . The elevated $\mathrm{pH}$ decreased nonspecific cellulase binding to lignin by increasing lignin surface charge and hydrophilicity [34]. The slight decrease of vanillin inhibition in this study may be caused by the potential-induced change of inhibitor-binding capacity, which needs to be studied further.

Changing temperature hardly alleviated inhibition of vanillin (Table 3). When hydrolysis temperature increased from 30 to $50{ }^{\circ} \mathrm{C}$, glucan conversions without inhibitor increased from 22.0 to $41.4 \%$ and glucan conversions with inhibitor increased from 14.4 to $26.9 \%$. However, the corresponding inhibition ${ }_{\text {app }}$ and inhibitorbinding constant were almost unchanged.

\section{Effect of chemical groups on inhibition}

We also investigated the inhibition of different phenolics compounds in enzymatic hydrolysis (Fig. 7). All the 
Table 1 Effect of additives on cellulose conversion ${ }^{\mathrm{a}}$ and apparent inhibition degrees

\begin{tabular}{llll}
\hline Additives & $\begin{array}{l}\text { Cellulose conversion } \\
\text { without vanillin (\%) }\end{array}$ & $\begin{array}{l}\text { Cellulose conversion } \\
\text { with vanillin (\%) }\end{array}$ & $\begin{array}{l}\text { Apparent } \\
\text { inhibition (\%) }\end{array}$ \\
\hline Blank $^{b}$ & $41.9 \pm 0.5$ & $26.8 \pm 0.6$ & $35.9 \pm 0.6$ \\
CaCl $_{2}^{\text {b }}$ & $42.8 \pm 0.2$ & $27.0 \pm 1.3$ & $36.7 \pm 0.5$ \\
${\text { Tween } 80^{b}}_{\text {Granular activated carbon }}^{\text {b }}$ & $42.0 \pm 1.5$ & $28.5 \pm 1.5$ & $32.2 \pm 1.5$ \\
Powdered activated carbon $^{b}$ & $39.7 \pm 0.8$ & $24.8 \pm 1.4$ & $37.5 \pm 1.1$ \\
BSA $^{b}$ & $28.6 \pm 0.6$ & $14.1 \pm 1.7$ & $50.5 \pm 1.0$ \\
Blank $^{c}$ & $42.0 \pm 1.0$ & $27.5 \pm 0.3$ & $34.6 \pm 0.6$ \\
BSA $^{c}$ & $41.9 \pm 0.5$ & $32.4 \pm 1.0$ & $22.6 \pm 0.3$ \\
BSA $^{c, d}$ & $40.8 \pm 0.3$ & $31.5 \pm 0.3$ & $22.8 \pm 0.3$ \\
\hline
\end{tabular}

${ }^{a}$ Enzymatic hydrolysis of Avicel was carried out with cellulose concentration of $10 \mathrm{mg} / \mathrm{mL}$ and cellulase concentration of $0.3 \mathrm{mg} / \mathrm{mL}$ at $50{ }^{\circ} \mathrm{C}$. Cellulose conversion was determined at $24 \mathrm{~h}$. The concentration of the additives was $2.5 \mathrm{mg} / \mathrm{mL}$

b Vanillin concentration was $5 \mathrm{mg} / \mathrm{mL}$

c Vanillin concentration was $2.5 \mathrm{mg} / \mathrm{mL}$

$\mathrm{d}$ Vanillin was pre-incubated $3 \mathrm{~h}$ with BSA before enzyme addition

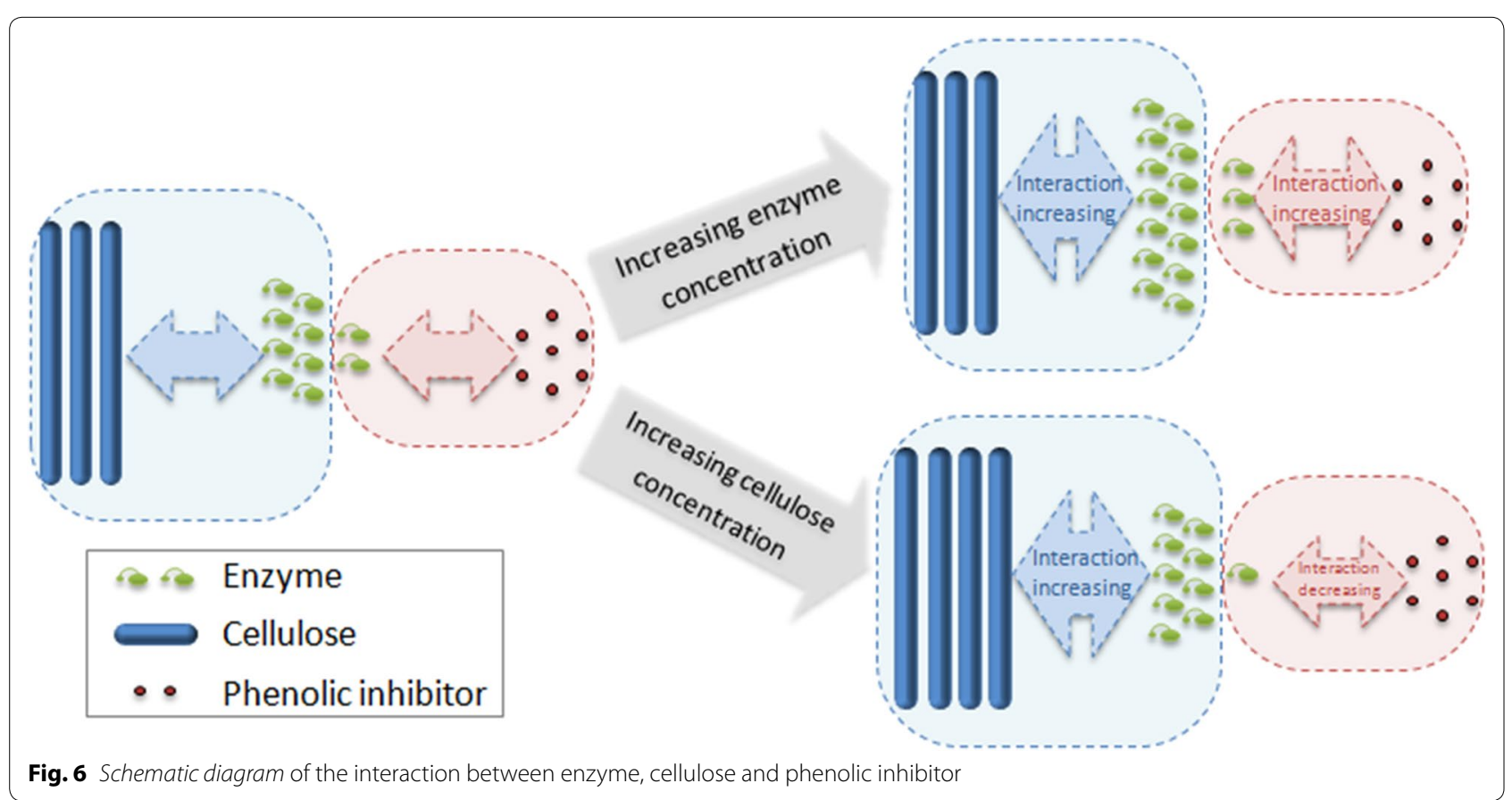

Table 2 Effect of pH on vanillin inhibition

\begin{tabular}{lllll}
\hline PH & $\begin{array}{l}\text { Cellulose conversion } \\
\text { without vanillin (\%) }\end{array}$ & $\begin{array}{l}\text { Cellulose conversion } \\
\text { with vanillin }^{\mathbf{b}} \text { (\%) }\end{array}$ & $\begin{array}{l}\text { Apparent } \\
\text { inhibition (\%) }\end{array}$ & $\begin{array}{l}\text { Inhibitor-binding } \\
\text { constant } \boldsymbol{\beta} \text { (vanillin, } \mathbf{m L} / \mathbf{m g} \text { ) }\end{array}$ \\
\hline 4.3 & $40.9 \pm 2.1$ & $26.3 \pm 1.8$ & $35.7 \pm 2.8$ & 0.1112 \\
4.8 & $41.4 \pm 0.6$ & $26.9 \pm 0.6$ & $35.0 \pm 0.9$ & 0.1092 \\
5.3 & $39.5 \pm 2.0$ & $26.6 \pm 0.3$ & $32.6 \pm 2.0$ & 0.0967 \\
\hline
\end{tabular}

${ }^{a}$ Enzymatic hydrolysis of Avicel was carried out with cellulose concentration of $10 \mathrm{mg} / \mathrm{mL}$ and cellulase concentration of $0.3 \mathrm{mg} / \mathrm{mL}$ at $50{ }^{\circ} \mathrm{C}$. Cellulose conversion was determined at $24 \mathrm{~h}$

${ }^{b}$ Vanillin concentration was $5 \mathrm{mg} / \mathrm{mL}$ 
Table 3 Effect of temperature on vanillin inhibition

\begin{tabular}{lllll}
\hline Temperature $\left({ }^{\circ} \mathbf{C}\right)$ & $\begin{array}{l}\text { Cellulose conversion } \\
\text { without vanillin }(\%)\end{array}$ & $\begin{array}{l}\text { Cellulose conversion } \\
\text { with vanillin }^{\mathbf{b}}(\%)\end{array}$ & $\begin{array}{l}\text { Apparent } \\
\text { inhibition (\%) }\end{array}$ & $\begin{array}{l}\text { Inhibitor-binding } \\
\text { constant } \boldsymbol{\beta}(\mathbf{v a n i l l i n}, \mathbf{m L} / \mathbf{m g})\end{array}$ \\
\hline 30 & $22.0 \pm 1.7$ & $14.4 \pm 0.2$ & $34.4 \pm 3.0$ & 0.1048 \\
40 & $35.7 \pm 0.6$ & $22.9 \pm 0.5$ & $35.9 \pm 1.6$ & 0.1121 \\
50 & $41.4 \pm 0.6$ & $26.9 \pm 0.6$ & $35.0 \pm 0.9$ & 0.1092 \\
\hline
\end{tabular}

a Enzymatic hydrolysis of Avicel was carried out with cellulose concentration of $10 \mathrm{mg} / \mathrm{mL}$ and cellulase concentration of $0.3 \mathrm{mg} / \mathrm{mL}$ at $\mathrm{pH} 4.8$. Cellulose conversion was determined at $24 \mathrm{~h}$

b Vanillin concentration was $5 \mathrm{mg} / \mathrm{mL}$

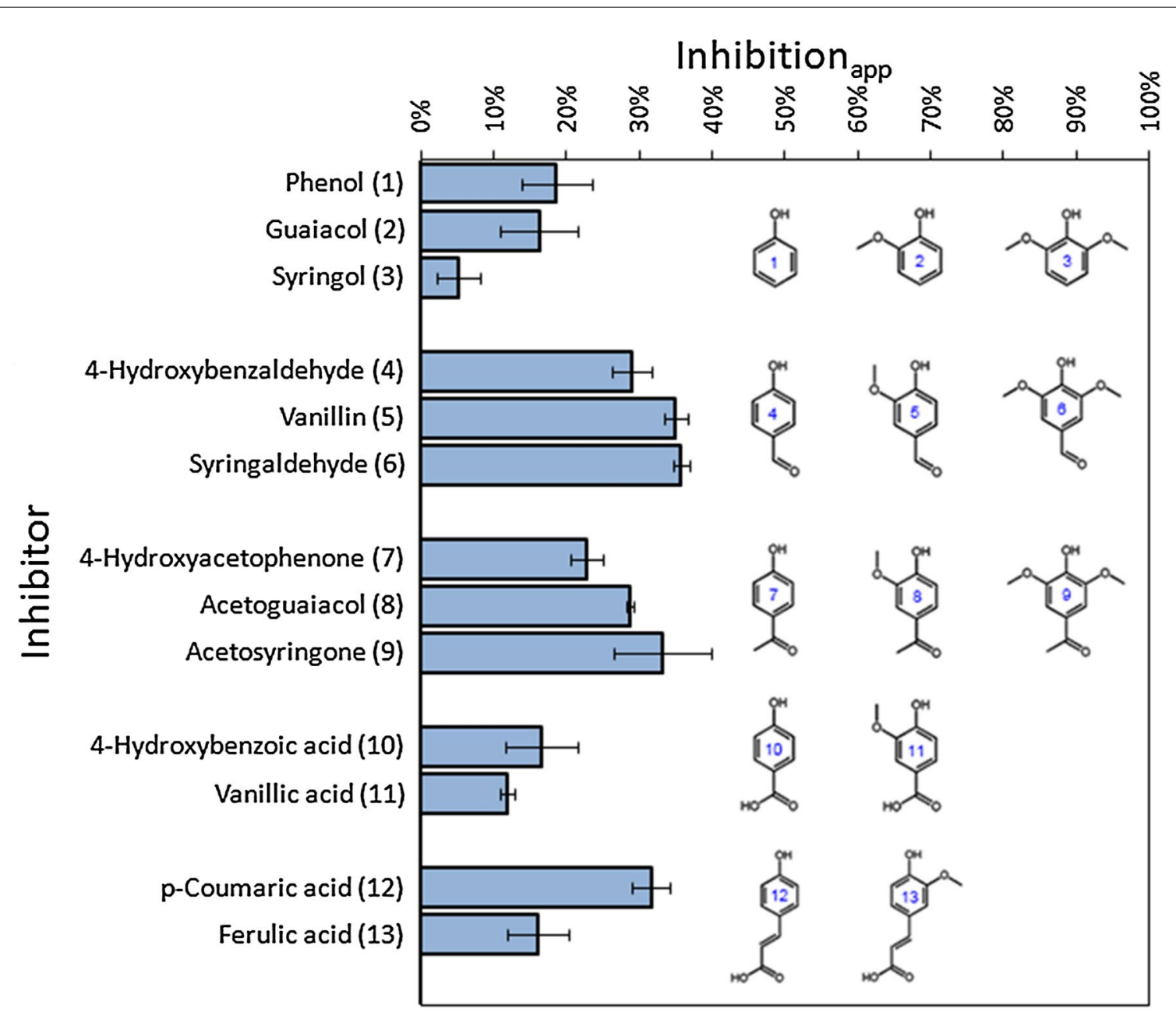

Fig. 7 Apparent inhibitions of different phenolic compounds. Phenolic concentrations are all $5 \mathrm{mg} / \mathrm{mL}$. Error bars represented standard deviations, $n=3$

phenolic compounds inhibited cellulose conversion and exhibited different inhibition $n_{\text {app }}$. Inhibition ${ }_{\text {app }}$ decreased as the adjunction of methoxy side chain at $\mathrm{C} 2$ and $\mathrm{C} 6$ for phenols, such as 4-hydroxybenzoic acids and $p$-coumaric acid. However, the increased inhibition ${ }_{\text {app }}$ was observed as the adjunction of methoxy side chain for 4-hydroxybenzaldehyde and 4-hydroxyacetophenone. For the specific aromatic unit $(\mathrm{H}, \mathrm{G}$, and $\mathrm{S})$, compounds with aldehyde and ketone group exhibited more inhibitory effect on cellulase than those with phenol and carboxyl group. It was reported that total hydroxyl groups in lignin had an important impact on cellulase adsorption 
and enzymatic hydrolysis [35]. Our results indicated that carbonyl group and methoxy group in phenolics also inhibit enzyme activity.

\section{Conclusion}

Vanillin significantly decreased enzyme activity and concentration during enzymatic hydrolysis. The inhibition degree $\left(A_{0} / A\right)$ was independent of the hydrolysis time. The increasing of cellulase concentration or cellulose loading slightly mitigated the inhibition of vanillin. The inhibition degree depended linearly on the inhibitor concentration and exponentially on the cellulose loading and the enzyme concentration. $\mathrm{pH}$, temperature, and the addition of calcium chloride, BSA and Tween 80 cannot mitigate the inhibition of vanillin significantly. The presence of hydroxyl group, carbonyl group, and methoxy group in phenolics exhibited the impact on inhibitions.

\section{Experimental}

\section{Materials}

Avicel PH-101 (containing $98 \%$ glucan and $2 \%$ xylan in dry matter) purchased from Sigma-Aldrich (St. Louis, $\mathrm{MO}$ ) was used as cellulosic substrate. The use of pure cellulosic substrate is in order to exclude the interference of other compositions in lignocellulosic material.

Commercial cellulase Spezyme CP preparation from Trichoderma reesei containing exo-, endo-, and $\beta$-glucosidase activities was provided by Genencor (Palo Alto, CA), which has a total protein concentration of $123 \mathrm{mg} / \mathrm{mL}$. The cellulase activity was determined as 59 $\mathrm{FPU} / \mathrm{mL}$.

Phenol, guaiacol, syringol, 4-hydroxybenzaldehyde, vanillin, syringaldehyde, 4-hydroxyacetophenone, acetoguaiacol, acetosyringone, 4-hydroxybezoic acid, and vanillic acid were purchased from Sigma-Aldrich (St. Louis, MO). p-Coumaric acid and ferulic acid were purchased from Aladdin (Los Angels, CA).

\section{Enzymatic hydrolysis}

Enzymatic hydrolysis was conducted with $20-\mathrm{mL}$ reaction volume in $100-\mathrm{mL}$ flask, with cellulase at $50{ }^{\circ} \mathrm{C}$ and $150 \mathrm{rpm}$. Avicel, phenolics, and cellulase were added to specific concentration or loading. $50 \mathrm{mM}$ citrate buffer $(\mathrm{pH} 4.8)$ and $20 \mathrm{mg} / \mathrm{L}$ sodium azide were used in enzymatic hydrolysis. $0.2 \mathrm{~mL}$ samples were withdrawn and frozen at $-20^{\circ} \mathrm{C}$ for subsequent HPLC sugar analysis.

\section{Analytical methods}

The National Renewable Energy Laboratory (NREL) LAP-004 protocol was used to determine the composition of Avicel. Glucose was analyzed by HPLC equipped with an Aminex HPX-87H column (Bio-rad, Hercules, CA) at $65^{\circ} \mathrm{C}$.
The protein concentrations of the enzymes were determined by the BCA protein assay.

\section{Additional files}

Additional file 1: Figure S1. Cellulose hydrolysis rate with different vanillin concentrations. Cellulose loading was $1 \%(10 \mathrm{mg} / \mathrm{mL})$ and cellulase concentration was $0.3 \mathrm{mg} / \mathrm{mL}$.

Additional file 2: Figure S2. Enzyme concentration in supernatant. wo: without; w: with; I: inhibitor; S: substrate. Vanillin concentration was 5 mg/ $\mathrm{mL}$. Error bars represented standard deviations, $\mathrm{n}=2$.

Additional file 3: Figure S3. Enzyme activity decreased as enzyme preincubation time went without (A) and with (B) $5 \mathrm{mg} / \mathrm{mL}$ vanillin addition. Enzyme activity was calculated by glucose concentration in hydrolysate within one hour. Cellulose loading was $1 \%$ and cellulase concentration was $0.3 \mathrm{mg} / \mathrm{mL}$. The enzyme activity of $0 \mathrm{~h}$ pre-incubation without vanillin addition was standardized as $100 \%$. Error bars represented standard deviations, $\mathrm{n}=2$.

Additional file 4: Figure S4. Cellulose conversions (A) and inhibition of vanillin (B) with different vanillin loadings at $24 \mathrm{~h}$ of hydrolysis. Error bars represented standard deviations, $\mathrm{n}=3$.

Additional file 5: Table S1. Inhibitor-binding constants of different cellulose and cellulose concentrations.

\section{Abbreviations}

$\mathrm{H}$ : hydroxyphenyl unit; G: guaiacyl unit; S: syringyl unit; Inhibition $\mathrm{app}_{\text {: }}$ apparent inhibition degree; $A$ : cellulose conversion with inhibitor; $A_{0}$ : cellulose conversion without inhibitor; l: concentration of inhibitor ( $\mathrm{g} / \mathrm{L}$ ); $\beta$ : inhibitor-binding constant (L/g); S: cellulose concentration $(\mathrm{mg} / \mathrm{mL})$; E: enzyme concentration $(\mathrm{mg} / \mathrm{mL})$; BSA: bovine serum albumin; HPLC: high performance liquid chromatography; FPU: filter paper unit.

\section{Authors' contributions}

LQ carried out the experiments, performed the statistical analysis, and drafted the manuscript. WCL, LL, JQZ, and XL participated in the experiments and helped to revise the manuscript. BZL and YJY conceived of the study and revised the manuscript. All authors read and approved the final manuscript.

\section{Author details}

${ }^{1}$ Key Laboratory of Systems Bioengineering (Ministry of Education), School of Chemical Engineering and Technology, Tianjin University, Weijin Road 92, Nankai District, Tianjin 300072, People's Republic of China. ${ }^{2}$ SynBio Research Platform, Collaborative Innovation Center of Chemical Science and Engineering (Tianjin), Tianjin University, Weijin Road 92, Nankai District, Tianjin 300072, People's Republic of China.

\section{Acknowledgements}

This study was financially supported by the Ministry of Science and Technology of China ("973"Program: 2013CB733601), the National Natural Science Foundation of China (Major program: 21390203), and the Tianjin Municipal Science and Technology Committee (No: 11ZCGHHZ00500).

\section{Competing interests}

The authors declare that they have no competing interests.

Received: 23 November 2015 Accepted: 10 March 2016 Published online: 22 March 2016

\section{References}

1. Luo L, van der Voet E, Huppes G. Biorefining of lignocellulosic feedstocktechnical, economic and environmental considerations. Bioresour Technol. 2010;101(13):5023-32. 
2. Zeng Y, Zhao S, Yang S, Ding SY. Lignin plays a negative role in the biochemical process for producing lignocellulosic biofuels. Curr Opin Biotechnol. 2014;27:38-45.

3. Chundawat SPS, Beckham GT, Himmel ME, Dale BE. Deconstruction of lignocellulosic biomass to fuels and chemicals. Annu Rev Chem Biomol Eng. 2011;2:121-45.

4. Studer HM, DeMartini JD, Davis MF, Sykes RW, Davison B, Keller M, Tuskan GA, Wyman CE. Lignin content in natural populus variants affects sugar release. Proc Nat Acad Sci. 2011;108(15):6300-5.

5. Liu ZH, Qin L, Li BZ, Yuan YJ. Physical and chemical characterizations of corn stover from leading pretreatment methods and effects on enzymatic hydrolysis. ACS Sustain Chem Eng. 2014;3(1):140-6.

6. Alvira P, Tomás-Pejó E, Ballesteros M, Negro MJ. Pretreatment technologies for an efficient bioethanol production process based on enzymatic hydrolysis: a review. Bioresour Technol. 2010;101:4851-61.

7. Singh S, Cheng G, Sathitsuksanoh N, Wu D, Varanasi P, George A, Balan V, Gao X, Kumar R, Dale BE, Wyman CE, Simmons BA. Comparison of different biomass pretreatment techniques and their impact on chemistry and structure. Front Energ Res. 2015;2:62.

8. Ko JK, Kim Y, Ximenes E, Ladisch MR. Effect of liquid hot water pretreatment severity on properties of hardwood lignin and enzymatic hydrolysis of cellulose. Biotechnol Bioeng. 2014;112(2):252-62.

9. Ko JK, Ximenes E, Kim Y, Ladisch MR. Adsorption of enzyme onto lignins of liquid hot water pretreated hardwoods. Biotechnol Bioeng. 2014;112(3):447-56

10. Kim Y, Kreke T, Ko JK, Ladisch MR. Hydrolysis-determining substrate characteristics in liquid hot water pretreated hardwood. Biotechnol Bioeng. 2015;112(4):677-87.

11. Rahikainen $J$, Martin-Sampedro R, Heikkinen H, Rovio S, Marjamaa K, Tamminen T, Rojas OJ, Kruus K. Inhibitory effect of lignin during cellulose bioconversion: the effect of lignin chemistry on non-productive enzyme adsorption. Bioresour Technol. 2013;133:270-8.

12. Guo F, Shi W, Sun W, Li X, Wang F, Zhao J, Qu Y. Differences in the adsorption of enzymes onto lignins from diverse types of lignocellulosic biomass and the underlying mechanism. Biotechnol Biofuels. 2014;7:38.

13. Berlin A, Balakshin M, Gilkes N, Kadla J, Maximenko V, Kubo S, Saddler J. Inhibition of cellulase, xylanase and $\beta$-glucosidase activities by softwood lignin preparations. J Biotechnol. 2006;125:198-209.

14. Nakagame S, Chandra RP, Saddler JN. The effect of isolated lignins, obtained from a range of pretreated lignocellulosic substrates, on enzymatic hydrolysis. Biotechnol Bioeng. 2010;105:871-9.

15. Ximenes E, Kim Y, Mosier N, Dien B, Ladisch M. Inhibition of cellulases by phenols. Enzyme Microb Technol. 2010;46:170-6.

16. Kim Y, Ximenes E, Mosier NS, Ladisch MR. Soluble inhibitors/deactivators of cellulase enzymes from lignocellulosic biomass. Enzyme Microb Technol. 2011;48:408-15.

17. Ximenes E, Kim Y, Mosier N, Dien B, Ladisch M. Deactivation of cellulases by phenols. Enzyme Microb Technol. 2011;48:54-60.

18. Du B, Sharma LN, Becker C, Chen SF, Mowery RA, van Walsum GP, Chambliss CK. Effect of varying feedstock-pretreatment chemistry combinations on the formation and accumulation of potentially inhibitory degradation products in biomass hydrolysates. Biotechnol Bioeng. 2010;107(3):430-40.
19. Kim Y, Kreke T, Hendrickson R, Parenti J, Ladisch MR. Fractionation of cellulase and fermentation inhibitors from steam pretreated mixed hardwood. Bioresour Technol. 2013;135(4):595-9.

20. Li BZ, Balan V, Yuan YJ, Dale BE. Process optimization to convert forage and sweet sorghum bagasse to ethanol based on ammonia fiber expansion (AFEX) pretreatment. Bioresour Technol. 2010;101:1285-92.

21. Qin L, Li WC, Zhu JQ, Liang JN, Li BZ, Yuan YJ. Ethylenediamine pretreatment changes cellulose allomorph and lignin structure of lignocellulose at ambient pressure. Biotechnol Biofuels. 2015;8:174

22. Qin L, Liu ZH, Jin MJ, Li BZ, Yuan YJ. High temperature aqueous ammonia pretreatment and post-washing enhance the high solids enzymatic hydrolysis of corn stover. Bioresour Technol. 2013;146:504-11.

23. Pan $X$. Role of functional groups in lignin inhibition of enzymatic hydrolysis of cellulose to glucose. J Biobased Mater Bio. 2008;2:25-32.

24. Tejirian A, Xu F. Inhibition of enzymatic cellulolysis by phenolic compounds. Enzyme Microb Technol. 2011;48:239-47.

25. Holtzapple M, Cognata M, Shu Y, Hendrickson C. Inhibition of Trichoderma reesei cellulase by sugars and solvents. Biotechnol Bioeng. 1990;36(3):275-87.

26. Zhao J, Chen H. Stimulation of cellulases by small phenolic compounds in pretreated stover. J Agric Food Chem. 2014;62(14):3223-9.

27. Kumar L, Arantes V, Chandra R, Saddler J. The lignin present in steam pretreated softwood binds enzymes and limits cellulose accessibility. Bioresour Technol. 2012;103:201-8.

28. Modenbach AA, Nokes SE. Enzymatic hydrolysis of biomass at high-solids loadings-a review. Biomass Bioenerg. 2013;56:526-44.

29. Sineiro J, Dominguez H, Núñez MJ, Lema JM. Inhibition of cellulase activity by sunflower polyphenols. Biotechnol Let. 1997;19(6):521-4.

30. Liu H, Zhu JY, Fu SY. Effects of lignin-metal complexation on enzymatic hydrolysis of cellulose. J Agric Food Chem. 2010;58:7233-8.

31. Yang B, Wyman CE. BSA treatment to enhance enzymatic hydrolysis of cellulose in lignin containing substrates. Biotechnol Bioeng. 2006:94(4):611-7.

32. Lu J, Li X, Yang R, Zhao J, Qu Y. Tween 40 pretreatment of unwashed water-insoluble solids of reed straw and corn stover pretreated with liquid hot water to obtain high concentrations of bioethanol. Biotechnol Biofuels. 2013;6:159.

33. Qi B, Chen X, Wan Y. Pretreatment of wheat straw by nonionic surfactantassisted dilute acid for enhancing enzymatic hydrolysis and ethanol production. Bioresour Technol. 2010;101:4875-83.

34. Lou H, Zhu JY, Lan TQ, Lai H, Qiu X. pH-Induced lignin surface modification to reduce nonspecific cellulase binding and enhance enzymatic saccharification of lignocelluloses. ChemSusChem. 2013;6(5):919-27.

35. Yu Z, Gwak KS, Treasure T, Jameel H, Chang H, Park S. Effect of lignin chemistry on the enzymatic hydrolysis of woody biomass. ChemSusChem. 2014:7:1942-50.

\section{Submit your next manuscript to BioMed Central and we will help you at every step:}

- We accept pre-submission inquiries

- Our selector tool helps you to find the most relevant journal

- We provide round the clock customer support

- Convenient online submission

- Thorough peer review

- Inclusion in PubMed and all major indexing services

- Maximum visibility for your research

Submit your manuscript at www.biomedcentral.com/submit
() Biomed Central 